\title{
Human and nonhuman rights ${ }^{1}$
}

\author{
Direitos Humanos e não-humanos
}

DARLEI DALL'AGNOL ${ }^{a}$

\begin{abstract}
This paper tries to rethink the notion of human rights and to evaluate whether we should redefine them in light of the main challenges presented by advances in technoscience (genetic engineering, robotics, nanotechnology etc.). It claims that there are basic, intrinsic rights to personhood, which, on the one hand, allow us to justify a moral claim to a posthuman existence (should it become possible) and to attribute rights to artificial agents, while, on the other hand, granting the moral entitlement to remain human. This shows that the notion of human rights is far from becoming obsolete, as claimed by some scholars. The paper is divided into five parts. It (1) presents reasons for rethinking the notion of "a right" in order to apply it to beings other than humans (e.g., nonhuman animals, robots etc.); (2) discusses the metaethical problem concerning the meaning of "a right"; (3) presents a basic system of rights that are intrinsic to personhood and that can be attributed to different kinds of agents (human or not); (4) analyzes whether there is a right to a posthuman existence or a right to remain human; and finally, (5) presents some reasons to justify such a system of rights.
\end{abstract}

Keywords: Human rights. Post-human existence. Post-human rights. Personhood.

\section{Resumo}

Este trabalho procura repensar a noção de direitos humanos e avaliar se devemos redefini-los diante dos desafios apresentados pela tecnologia (engenharia genética, robótica, nanotecnologia etc.) 0 artigo sustenta que há direitos básicos, intrínsecos à

\footnotetext{
${ }^{1} \mathrm{~A}$ previous version of this paper was published in Portuguese in "Ética, Direitos Humanos e Socioambientalismo", edited by Cleide Calgaro e Idalgo José Sangalli (Caxias do Sul: UNESCO/EDUCS, 2018). I would like to thank the organizers for the authorization to publish an expanded English version and $\mathrm{CNPq}$ for supporting my research project "Philosophical Foudations of Neurobioethics".

a Universidade Federal de Santa Catarina, Florianópolis, Brasil. Doutor em Filosofia, e-mail: ddarlei@yahoo.com
} 
pessoalidade que, por um lado, permite justificar a reinvindicação a uma existência pós-humana (caso se torne possível) ou atribuir direitos a agentes artificiais $e$, por outro lado, fundamenta o direito a permanecer humano. Mostra-se, então, que a noção de direitos humanos, ao contrário do que alguns estudiosos sustentam, está longe de tornar-se obsoleta. O trabalho está dividido em cinco partes: na primeira, apresenta razões para repensar a noção de "direito" e aplicá-la a outros agentes que não são humanos (por exemplo, animais não-humanos, robôs etc.); na segunda, discute os problemas metaéticos sobre o significado de "ter um direito"; na terceira, apresenta um sistema de direitos básicos intrínsecos à pessoalidade que pode ser atribuído a diferentes agentes (não somente humanos); na quarta parte, analisa se há um direito a uma existência pós-humana ou a permanecer humano; e, finalmente, apresenta algumas razões para justificar tal sistema de direitos.

Palavras-chave: Ética. Direitos. Direitos humanos. Pós-humanos.

\section{Introduction}

We just celebrated the $70^{\text {th }}$ anniversary of the UN's Universal Declaration of Human Rights, adopted by the General Assembly in December 1948. One reason to rejoice was that almost all countries have adopted its recommendations, incorporating most rights into their legislation. Another is its likely role in avoiding another major global conflict and bringing a certain political stability to our planet. For these and perhaps many other reasons, the idea of universal human rights has become a kind of general moral standard in our contemporary world. There are, of course, many problems in their application and innumerous practices that disrespect them, but the progress is unquestionable. Moreover, many similar declarations have followed it in an attempt to fill in the gaps. For instance, there is the American Convention on Human Rights, known as "The Pact of San José, Costa Rica," which Brazil incorporated into law in 1992, albeit with some restrictions. This convention restates the traditional charter and creates institutions to uphold the rights within it, for instance the Inter-American Court of Human Rights. There are also specific documents such as the Universal Declaration on Bioethics and Human Rights (UNESCO, 2005) drafted to protect the rights of participants in scientific experiments, and so forth.

The development of science and technology, especially genetic engineering and AI (Artificial Intelligence) is, however, jeopardizing the very notion of buman 
rights. There have been many scientific discoveries and associated artifacts (weapons of mass destruction) which have led people to predict the end of the Homo sapiens species (if an environmental catastrophe does not occur first). For example, recent techniques to edit our genome (especially, CRISPR-Cas9) could well be used to produce new beings that should in some sense be considered trans or even posthumans. In other scientific fields, there are attempts to integrate the mind/brain with machines, making possible what is known as "Singularity" (the complete integration of mind and machine enabling us, some scholars believe, to upload ourselves-predicted to happen in around 2045 or even before that). We will become virtually immortal or able to create artificial brains capable of simulating human states of mind. Thus, there will be "digital persons", beings without biological bodies. This is highly speculative, of course, but not impossible. We need, then, to ask whether there is, somewhat paradoxically, a human right to remain human or a right to become posthuman. If so, what would a Universal Declaration of Posthuman Rights look like? Robotics is developing fast and producing artificial agents, such as Sophia the smart robot, who, in some sense, need to be considered persons (if we do not take "person" as a synonym for "human being" only) and citizens. What should be in a Universal Declaration of Robot Rights if robots become agents capable of following rules, that is, if they become autonomous beings?

In this paper, I would like to rethink the notion of buman rights and discuss whether we need to re-signify them in light of the main challenges from technoscience (genetic engineering, robotics, nanotechnology etc.). It is my thesis that there are basic, intrinsic rights to personhood, which, on the one hand, allow us to justify a moral claim to a posthuman existence (when it becomes possible) and to attribute rights to artificial agents, and on the other hand, to grant the moral entitlement to remain human. In this way, pace others writing about human enhancement, for instance Fukuyama (2003), I will argue that the notion of buman rights is not becoming obsolete. It is almost unnecessary to stress that my point is a preliminary one and that many philosophical issues remain open. My central aim, however, is to maintain that the very idea of human rights will continue 
to make sense even in a posthuman world. As is well known, the question of whether there are human rights or not is a philosophical problem that has been discussed since Jeremy Bentham rejected the idea (1948, 335-6) by arguing that there are only legal rights.

In order to achieve my main objective, I will divide the paper into five parts. In the first, I will present some reasons why we need to rethink the notion of "a right" beyond humans (e.g., in relation to nonhuman animals, robots etc.). In the second part, I will discuss the metaethical problem of What is meant by "a right"? In the third, I will present a basic system of rights intrinsic to personhood, which we can attribute to different kinds of agents whether human or not. In the fourth part, I will analyze whether there is a right to a human postexistence or a right to remain human. Finally, I will present some reasons to justify such a system of rights.

\section{1 - What would a posthuman person look like?}

In his essay The Abolition of Man, C. S. Lewis (1943) scrutinizes our conquest of nature as a means of describing the progress of applied science. For him, the airplane, the wireless and contraceptives are clear examples of humans' power to control nature to our advantage. But Lewis (1943, p. 24) was also well aware that "Each new power won by man is a power over man as well". Each generation exercises greater power over the previous one with the aid of new scientific or technological developments, for instance either through eugenics or through education.

The greater human power over natural processes, however, could ultimately lead to the abolition of man. Thus, according to Lewis (1943, p. 25), the final stage will arrive when mankind through eugenics, pre-natal conditioning and an education based on applied psychology, “[...] has obtained full control over himself. Human nature will be the last part of Nature to surrender to Man. The battle will then be won". Clearly, we are on the way! It is difficult not to recall here another book, namely Brave New World by Aldous Huxley, which predicts full human control over reproduction by the year 2540. Writing well before the discovery of DNA (1953), the Human Genome Project (1990-2003), similar projects (e.g., the more recent 
B.R.A.I.N. Initiative, Brain Research through Advancing Innovative Neurotechnologies) and predictions such as the Singularity, Lewis foresaw that final control over nature would be won, but that it could also mean the abolition of humanity.

Just in case the reader is not fully convinced, I would briefly like to further explore one of these possibilities, namely how the conquest of nature will eventually lead to a posthuman world. Genetic engineering is already being used on a large scale to change the form and structure of many biological organisms, mainly plants and nonhuman animals. Specific examples are the introduction of new genes to produce fluorescent green rabbits; a mouse that can run twice as fast a normal one; and pigs with human organs. Nonhuman rights supporters protest that the interests of these beings are not taken into consideration. I will not discuss this point here, but I acknowledge without further argumentation that some nonhuman animals are capable of agency and consequently should be protected with rights. According to the primatologist Frans de Wall (1997, p. 75), bonobos weave an intricate web of political arrangements which presuppose effective cooperation. How could cooperation be possible without a minimal capacity for action? They have the necessary attributes to understand and follow rules and, therefore, should be considered persons. The same reasoning applies to most apes and perhaps to other species such as dolphins. Thus, a Universal Declaration of Animal Rights should be legally enforced by all countries. What it should contain, however, is a matter of great controversy, but I will not discuss it here. I will just assume that there are nonhuman animals with rights. Therefore, the concept of "rights" does not apply to humans only.

The use of techniques such as CRISPR-Cas9 on humans raises issues around the ethical limits of genetic engineering or genome editing. There is no doubt that, if they are efficient and safe, they can be used for curative purposes, but there is much debate concerning whether they should be allowed for physical and cognitive enhancement for example, since the specter of Nazism always hangs over eugenic proposals. There is, however, no doubt that if they were allowed in legislation, these genetic editing techniques would have the potential to lead to a trans or posthuman world and the creation of beings with superhuman capabilities. 
In the nearer future, cyborgs-" "normal or natural" humans with implanted high-tech artifacts able to perform more-than-human activities-are a possibility and would have to be considered transhuman in some sense. We are all familiar with the concept of artificial supports being integrated with the body (glasses, prosthetics etc.), but no one calls for the conditions under which we are considered to belong to the Homo sapiens species to be revised. In terms of overcoming the basic human condition, the existence of artificial legs that can make a person run faster than the fastest natural human has yet to become a huge concern. But if, for example, it were possible for two humans with artifacts implanted into their brains and capable of accessing the internet to communicate "telepathically" in front of us without our knowing, that would lead us to us wonder whether they did not have something extra, something more-than-human. But what would the Universal Declaration of Cyborg Rights look like? It is not my aim here to make any such proposal, only to point out the idea that technoscience is making it possible to overcome the human condition in such a way that the elimination of the human species is becoming a closer reality. We need, therefore, to rethink the notion and the meaning of "have the right to", because a right cannot just mean a natural property of a species in the sense of "buman rights".

There is much to be discussed, including the features that would belong to one species and not another. For instance, what makes a Hominidae a sapiens and not a habilis or erectus? Brain size? Specific abilities? A sophisticated language system? What else? In any case, it does not seem difficult to imagine a posthuman. Suppose a person survives a car accident but loses both legs and becomes a cyborg able to control her new artificial limbs using her mind only. Now imagine she is capable of running $100 \mathrm{~m}$ in less than 5 seconds, something no natural human will ever be capable of, or that she can leave her legs in another country and, by controlling them, harm another person or use them to kill someone. Can she still be considered buman? Does she belong to Homo sapiens? No sapiens can "mentally" control her far away legs. Such a person should be considered transhuman or as a member of a new species: Homo X. 
Let us suppose that in the not very distant future, neuroscience and neurotechnology make it possible for us to share a common consciousness by accessing one another's brains to form a collective memory. For those familiar with sci fi scenarios, think of the Borg in the Star Trek series, a collective species without any sense of individuality. Would such a species still be human in any sense? What characterizes humanity? Rationality? Self-awareness? Capacity to love? Language? Sociability? The power to imagine? Mortality? A sense of individuality? Whatever the most appropriate answer, our species is categorically distinct from the Borg. If Borgs were created, we would have to grant rights to collective persons just as we do to institutions. But what would the Universal Declaration of Collective Persons' Rights look like?

I would now like to go a step further. Imagine that machine learning, powered by Artificial Intelligence, develops to a point well beyond the original intentions of human designers. Suppose a human person uploads her mind into such a machine, which continues to add new memories, new ways of calculating/thinking, and so on. Imagine also that she learns how to duplicate or reproduce herself. Would that machine be a person? Would it be an artificial agent with basic rights, but also open to the development of new rights over time? Which rights? What kinds of obligations will she have? To illustrate this, let's introduce a character, Ray, a posthuman person named after Raymond Kurzweil. Imagine that the physical author of The Singularity is Near lived until he could upload his mind into a computer. Afterwards, his body would die, but he would also be capable of acquiring a new one (perhaps out of his own genetic makeup using cloning techniques) and downloading himself back into the new body indefinitely, perhaps as in the dystopia Altered Carbon. Would a society with such individuals, living side by side with mortal humans, be fair?

To end this first section, it seems clear that such posthuman scenarios bring us to the issue of whether if having human rights would still make sense. To deal with this subject adequately, we need to rethink the question What is meant by " $a$ right"? This is a metaethical question. To provide an acceptable answer, it is crucial that we understand the UN's Declaration and discuss whether it would still remain 
universal or would have to be restricted to a particular kind of being, we humans, who would coexist with both nonhuman animals who are also persons and artificial agents such as robots, digital autonomous beings and so on.

\section{2 - What does it mean to have a right?}

In this section, I will briefly clarify the nature of statements such as "P (any person) has a right to $\mathrm{x}$ ". I will consider various issues in my attempt to make sense of the main idea that there are intrinsic rights to personhood. A proper account of the nature of rights will enable me to outline a system of such rights in the next section.

What does it mean to have a right, and a corresponding obligation? To obtain a satisfactory answer we need to start by pointing out the differences between moral rights and legal rights. Legal rights are quite simply rights laid down in the law. But this is obviously unsatisfactory in our context since we do not yet have legislation regulation rights and obligations for robots, digital persons and so forth. Then, the question is a moral one, namely what rights should these persons have once they have been created? Furthermore, the question of whether there are intrinsic rights to personhood is independent of whether a particular jurisdiction grounds them or not.

I would like to begin with the easiest part, namely, legal rights. To understand what a legal right is, we can use Hohfeld's analysis, which is the best the literature has to offer thus far. A legal right can mean a privilege; a claim; a power, or an immunity. According to Hohfeld (1919), a person A has the privilege to act or be in a certain state if she does not have a duty to act or be in a certain state (e.g., I have the right to express my thinking, not an obligation to do so); or, A has a claim if another person $\mathrm{B}$ has a duty to A (e.g., I have a right to life and, consequently, you have a duty not to kill me); or, A has a power if she has the ability to alter her own privileges or claims (the government can authorize the killing of an enemy, overriding the "right" to life); or, finally, A has an immunity, if B lacks the ability to alter A's privileges or claims (e.g., the government cannot force me to have a particular religion). Further specification of these meanings of legal rights need not concern us here since I will 
focus on the moral sense of "right" (and its corresponding obligations). I propose to restrict my Hohfeldian analysis to the meaning of legal rights. But not all legal rights are moral ones since, for instance, a lawful benefit may clearly be unjust. A moral right, as we will soon see, can be understood as relating to the intrinsic properties of the person herself and can never be said to be unjust.

What does it mean then to have a moral right? A plausible and simple answer seems to be this: it is a person's right independently of it whether if it is set out in any legislation. For instance, if a human has a right to life, this is so quite independently of whether a particular country recognizes that right in its jurisdiction or not. A human right to life is a title a person has qua human. To use an oldfashioned term, it is a natural right. But this negative characterization has to be complemented by a positive one stating the particular features of a moral right. Now, if we go back in the history of ethics, there was always fierce argument over whether there are natural/moral rights. Moreover, there was no agreement on which natural rights a human presumably has by virtue of belonging to the human species: Hobbesians held that an individual's sole non-transferrable right in the state of nature is precisely his right to life; Lockeans argued that humans have, apart from the right to life, a natural right to liberty, health and property in the state of nature; Kantians thought that a person's only innate right is freedom (and some associated equality rights that could be inferred from it). These disagreements may be due to a lack of clarity over what a natural right is. Let us first focus on what a moral right is, and then look for a better conceptual characterization.

Arguably the best answer to what a moral right is seems not to be that it is a natural one, but that it is an entitlement a person has qua person. In my view, a right is an intrinsic property of personhood itself. As such, it is clear that it is independent of any natural species and of any particular national legislation. In other words, basic or fundamental rights are a necessary condition to agency and, consequently, to morality itself. Inspired by Ernst Tugendhat (1994) and James Griffin (2013), I will call these rights "intrinsic rights". They are, as we will see in the next section, constitutive of personhood: to be a person just is to be an agent with intrinsic rights 
and corresponding obligations. Moral rights, therefore, are intrinsic properties of the person qua person, whether human or nonhuman.

A further necessary distinction must be made in relation to the kind of being a person is. That is to say, the same intrinsic right could be classified differently in relation to humans and in nonhumans. For instance, a right to life may be a proper human right (and a nonhuman animal right too), but not one an artificial agent necessarily has. A robot such as Sophia may have a right not to be arbitrarily destroyed, or something like that, but perhaps not a right to life. In any case, an intrinsic human right to life is a proper moral right independent of nationality, gender, ethnicity, religion and so on. It seems that we need to find a new common language to characterize such intrinsic rights. To illustrate, we could consider a basic, fundamental right to existence, meaning both a right to life for humans and nonhuman animals and for robots a right not to be destroyed and for digital persons a right not to be deleted. There is something contingent, varying with the kind a being one is, but ultimately properties such as the right to a safe existence would be common to all persons. Moreover, some of these contingent, extrinsic rights may be temporary and relative to the kind of person concerned, for instance, a human parent's right to decide the best education for her children.

An intrinsic right is a necessary and universal property of personhood. It can even be justified aprioristically: it is a constitutive condition of morality itself. It cannot be violated without substantial harm to personhood except in the name of another basic or fundamental right. To violate an intrinsic right is to annihilate morality. Such rights are entitlements, not just claims. Each intrinsic right has a corresponding obligation either relating to the person herself or that generates a duty to others across the ethical space. In the next section, I will outline a system of such intrinsic rights to illustrate these theoretical points.

\section{3 - Rights intrinsic to persons}

What I have called "intrinsic rights" are the necessary conditions for an individual to be a person, that is, they are the entitlements of the person qua person. 
In other words, they are constitutive properties of personhood. Conceived in this way, they allow us to think of rights as moral rights, without restricting them to beings that are members of our species. We can ascribe them to nonhuman animals as well as to artificial agents or supranatural beings (should there be any).

In this section I would now like to consider a provisional basic system of such rights to test whether the concept I have spelled out makes sense. The goal is not a list with a complete enumeration of such rights, but to illustrate how we may expand the idea of moral rights to nonhuman persons (natural or artificial). It is worth keeping in mind that such rights intrinsic to personhood are entitlements of the agent qua person whether a member of our species or not.

Inspired by Henry Shue's notion of basic rights (1980, 18f.) - the trichotomy: security, subsistence and liberty - I will divide the set of intrinsic rights into three categories. The main rights a person qua person has are: the rights to a safe existence; to basic equalities and fairness; and to political and civil liberties.

The first group of intrinsic rights and obligations comprises properties without which there would be no persons at all; that is, they guarantee the existence of moral beings capable of acting and being accountable for their deeds. In some sense, then, they are the most fundamental rights we can conceive of. In the case of humans, they are found under the article of the right to life in many declarations. According to some philosophers in the Hobbesian tradition, the right to life is the only real "natural" right a person can never forgo. This group of rights does not include the integrity of the person in a negative sense only, as freedom from violations leading to murder, torture, arbitrary arrest and so on. It includes most traditional rights to security. But this right, in our human case, does also include the basic necessities of access to air, water, shelter and nourishment, which are conditions for human beings to become and remain persons. I believe Henry Shue (1980, p. 24-5) has convincingly shown that what he calls "subsistence rights" (or "minimal economic security": unpolluted air, unpolluted water, adequate food, adequate clothing, adequate shelter, and minimal preventive public health care) are as basic as security rights: they are conditions that are required before any other rights can be enjoyed. There is no doubt that having adequate nutrition is as 
fundamental a condition to being a human person as is not being subjected to murder, torture, rape, assault and so on. That is why I put them together here, since they are both conditions of a safe existence. Shue keeps them separate, but, in my view, we can group them together given their internal links. Besides, his system is incomplete as it does not take equality rights seriously enough. There is no doubt that both security and subsistence rights are conditions required for a safe existence. If a person needs to work to subsist, then the right to work and to rest must be grounded too. In the case of artificial agents or other moral beings such as nonhuman animals or even extra-terrestrial lifeforms (if they exist at all as agents), the specificities of this right are less clear, but we can at least say that they have a right to be, to exist. For artificial agents, instead of food, electricity as a source of energy could be a basic right to a safe existence. This group also includes rights that protect physical integrity, for instance, the right not to be murdered, not to be seriously impaired, not to be significantly incapacitated in relation to personhood, such as in the ability to deliberate and decide to act autonomously. It is important to bear in mind that one person's rights means obligations for all others. However, sometimes these obligations are not placed on particular individuals, but on institutions such as the state. Therefore, they provide justification for the institutionalization of an artificial person.

The second group of intrinsic rights and obligations is also constitutive of personhood. To deny that persons are equal is not to recognize a fundamental property of their very nature as moral agents. The intrinsic rights to equality and fairness, excluding the equal right to exist and equal right to be free, are better specified as a set of rights and obligations that establish equality as required by the principle of the rule of law. Equality is a fundamental element of the notion of justice itself, arguably the most basic one considering both Aristotle's and Mill's ethics, which legitimates the rule of law. This is where principles such as all are equal before the law find their justification, as well as rights such as the presumption of innocence until proven guilty, a fair public hearing and an impartial judgement in a fair trial. It is, however, a formal notion of equality, which depends, in the human case, on another notion of equality, namely the effective material conditions 
provided through healthcare and education, including instruction on rights and obligations. There is no doubt, however, that moral equality grounds juridical and political equality and economic equity. Here the notion of fairness comes in, requiring us to treat all equals equally and allowing for different treatments for unequal individuals who require more or less attention, for instance, regarding their well-being assistance. For any members of our lifeform, assistance in health and education is necessary to become a person like any other. These are, together with the intrinsic right to a safe existence, constitutive of our personhood. This shows that all intrinsic rights are somehow interconnected and that the community of all persons is an egalitarian one. Once again, it is worth pointing out that any person's basic rights are accompanied by obligations for other persons, and here we can see that the right to equality justifies the obligation of the state to provide healthcare and a basic education for all.

The third set of intrinsic rights and obligations is also constituted by the fundamental properties of a person, understood as a free agent, that is, as an entity capable of acting. According to Kant, there is just one original right, an innate right to freedom (6: 237), from which it is possible to infer other rights. If the present system is sound, however, then Kant's restriction seems implausible. Regardless, basic social liberties such as freedom of movement and assembly, freedom of speech, freedom to hold property, freedom to hold public office and to vote and be voted for (to take part in government) and freedom to (not) hold religious beliefs are all requirements of the person qua agent and, consequently, are expressions of the political elements of a public morality. Another example is that freedom of consciousness is undeniable since a person is a self-conscious agent capable of deliberating and making decisions. Freedom of speech can be limited by two conditions: to speak the truth; and not to deny other persons intrinsic rights. This group of intrinsic rights may include freedom from poverty, slavery, torture, forced labor and not only freedom of thought, expression, and conscience and the right to privacy, that is, the traditional negative rights. Non-interference is not sufficient for true freedom. A person is truly free only if she can exercise her basic social and political liberties. Thus, most of the so-called "economic, social and cultural rights" 
fall into this group, such as the right to a basic education in order to reach the full development of human personhood. Thus, personhood is conditional on elementary education as well as basic assistance in healthcare and so these are intrinsic social and political rights. In this sense, it is closely connected to the first and second groups. In fact, together they constitute the human person qua person. Any of the rights in the first two groups to which a person is entitled generates a corresponding obligation on all other persons across the ethical space.

The conclusion then is that intrinsic rights make sense and can be understood as belonging to any person not only to humans. To be a person just is to have such rights, irrespective of whether that person is a natural or an artificial person. Bearing this point in mind, I would now like to discuss whether there is such a thing as a human right to remain human or a human right to a posthuman personhood.

\section{4 - Is there a right to remain human and a right to become a posthuman?}

One implication of the above reconceptualization of "moral right" as an intrinsic property of personhood is that the idea of human rights remains solid, but circumscribed to the members of our species. They could still be said to be universal, and we could add specific rights to the list according to the contingencies of our lifeform. But if it makes sense to speak of nonhuman animal rights and of robot rights, then we need to expand the moral community to include all kinds of persons.

One apparently paradoxical question arising out of the first section is whether there is a buman right to remain human or remain sapiens, and whether there is also a right to become a posthuman, so long as we keep our personhood. We could ask whether we humans do not have the obligation - if scientific evidence were presented to show that our species was, for instance, responsible for the Neanderthal extinction and given the possibility of bringing them back - to repair the harm we have done by using genetic engineering to (re)create species. The question then would be what kind of rights could they have? What would a Universal Declaration of Neanderthal Rights, or of Erectus or Habilis Rights, look like? 
To clarify this point I would like to go back to the case of posthuman Ray presented above. Can we prohibit Raymond Kurzweil from becoming posthuman by uploading his personality into a machine? Can we prohibit him from subsequently downloading himself into a new human body produced by genetic editing techniques such that he would be considered transhuman? Many (bio)ethicists hold that we should not allow the genetic manipulation of the human genome. Perhaps there is a human right to remain human, that is, to have unaltered DNA. Bioconservationists such as Michael Sandel (2007) have argued that we must be grateful for our natural gifts. I do not think, however, that our nature is perfect; there is plenty of room to enhance it, as philosophers such as Julian Savulescu (2009; 2011) and others have argued. Perfection does not of course exist, but there is no human essence either.

In the same direction, Habermas (2001) argued that under liberal eugenic policies parents' power to choose the genetic constitution of their descendants would break the asymmetry between persons making it possible for them to sue if they did not like the decisions made on their behalf. According to the author of The Future of Human Nature, our existing legal systems are based on the assumption that what we really are is the result of contingent and occasional variables that exclude the possibility of offspring charging their parents for the kind of being they are. This argument makes sense only if we assume genetic determinism, which clearly is not the case. Moreover, Habermas is highlighting the degree of difference and not difference in kind from what we already do, for instance, by choosing a school for our children. Again, we could ask if future generations could hold us responsible for not providing them with the best possible opportunity. The central point, however, is that Habermas is ultimately relying on an ethics of species and seems to have nothing to say about interspecies morality.

Some existing official declarations contain bioconservative assumptions; others are not clear on a great many important points. For instance, Article 16 of the Universal Declaration of Bioethics and Human Rights deals with the protection of future generations: "The impact of life sciences on future generations, including on their genetic constitution, should be given due regard". There are no specific 
guidelines: nothing is said on whether we should intervene in the human genome to prevent disabilities or diseases (for therapeutic purposes only) or to enhance normal human capabilities. "The Pact of San José, Costa Rica" is not clear on this point either. On the other hand, The 1997 Oviedo Convention, which regulates biomedical issues across the European Community states in Article 13: "An intervention seeking to modify the human genome may only be undertaken for preventive, diagnostic or therapeutic purposes and only if its aim is not to introduce any modification in the genome of any descendants." Most European countries (around 25) ratified the convention, including Germany, but many countries did not because they thought it too restrictive. Thus, the question is whether we can prohibit parents from altering their descendants' genome in an attempt to prevent them from becoming posthumans.

Being able to change our biological form in significant ways is not a remote possibility. As I pointed out above, editing techniques such as CRISPR-Cas9 make this scenario a very real one, but there are many ethical issues. A few years ago, Nature called for a moratorium on research and experiments which have the potential to change the human genome. Suppose, however, that it will soon be possible to make substantial modifications, for instance by introducing a new chromosome that humans do not possess. We could not consider these new beings. They would be trans beings or posthumans. If a new kind of homo is produced with super capabilities or, lets' say, new limbs such as a pair of wings, then it would be a new species. Is it morally wrong to make such changes?

Before trying to answer that question, I would like to go back to the issue of whether human rights are becoming obsolete because of new applications of science and technology. Perhaps the best stance on this is Allen Buchanan's in Beyond Humanity (2013). I agree with him that: (i) in a world in which some but not all were enhanced to the point of becoming posthumans, the concept of human rights, far from becoming obsolete, would become even more important; (ii) posthuman persons would have specific rights, but not a higher moral status than human persons. I will comment on these two points presently, but first I would like to discuss another of Buchanan's points, namely that the inequality between humans and 
enhanced posthumans will be less significant if we take some measures now. I believe we must be truly concerned with fairness in a posthuman world.

One reasonable concern of those who are against enhancement seems to be that posthumans will consider humans morally inferior. But if the system of intrinsic rights presented above is sound, then so long as personhood is preserved, reciprocal respect between all different kinds of agents can be enforced. Thus, it does not make sense to speak of "postpersons," only posthumans. A person is an agent with rights and obligations. She must be cared for and respected independently of whether she is a human, nonhuman animal or an artificial agent such as an autonomous robot. Physical enhancement would not make a person morally better or superior. She would have the same intrinsic moral rights as any person, for instance, basic equalities and liberties. Consequently, posthumans might be physically, but not morally, superior to us. They could be faster, cleverer and so forth, but they would not be morally better. In other words, they will have the same moral status as any person. Therefore, protecting the intrinsic rights spelled out above, including human rights or rights relative to any other species, would be crucial in a posthuman world where we live together with other kinds of agents.

What will very likely occur, however, is an increase in the social and material inequalities between humans and nonhumans. Thus, I argue that, despite Buchanan's optimism, enhancement will produce a society that will deepen existing injustices. Buchanan proposes (2013, p. 255) the creation of an institution to deal with this, a Global Institute for Justice in Innovation (GIJI), which would be similar to the World Trade Organization (WTO): a mechanism for proposing and implementing a set of rules and policies governing the diffusion of innovation on sound principles. The details of such an institution will not be scrutinized here, but it is worth pointing out that the main function would be to use innovation to promote justice and avoid an increase in social and material inequalities between humans and nonhumans. I am somewhat skeptical of whether such an institution could work without substantial reform in the current world order, including transforming the UN in the direction of a global or world state with the power to implement proposals such as the GIJI. Such a state, perhaps with multiple levels of 
administration and legislation, would have to be capable of implementing public policies to satisfy the basic needs of all agents: humans will need something like a universal basic income as proposed by van Parijs (2003), but perhaps other kinds of person will need something else (e.g., nonhuman animals will require proper habitats; artificial agents will need clean sources of energy). There are other necessary institutions such as a more effective international court of justice, but I will not argue this point here. What I would like to underline is that, if we assume a concept of justice as fairness (RAWLS, 1993), then we must be serious about giving priority to the satisfaction of basic needs before distributing liberties equally and allowing for social and material differences. A fair posthuman society must take equity seriously. For this reason, I do not see how the GIJI could function without a better world institutional structure guided by a democratic global state.

We are now in a position to answer the question of whether there is a human right to remain human and a right to transform oneself into a posthuman. I believe we can answer both questions positively, so long as personhood is preserved together with the set of intrinsic rights spelled out above. Consider again Ray, someone who could become a "transcendent man", a person who overcomes his biological condition to become a digital autonomous entity. I am aware that this is polemical and speculative, and I do not intend to give a final view here, but I believe there are no moral reasons for not allowing a human being to upload his mind into a machine and become a digital person. That is to say, as long as personhood is preserved, reciprocal respect and mutual care would guarantee peaceful coexistence, making possible many forms of cooperation between humans and nonhuman artificial agents. There is no reason to believe that a plural moral community comprising nonhuman animals, humans, robots, digital persons and so on would not be a good place to live. This is not a distant future, and we must prepare ourselves to coexist with artificial agents. We will have to respect them and they will have to respect us in turn, each fulfilling our corresponding obligations.

Given this scenario, we need to develop many areas of practical ethics, especially Roboethics. Asimov's three laws (a robot may not injure a human being; a robot must obey orders given it by humans except where such orders would conflict 
with the first law; and a robot must protect its own existence providing such protection does not conflict with the first two laws) need to be revised. Clearly, they do not reflect an equal relationship between humans and nonhumans based on mutual care and reciprocal respect, but rather an asymmetrical one. Unfortunately, I cannot develop this point further, but remind the reader of the need to take seriously the above system of intrinsic rights and refer to other research on this point (LIN; ABNEY; BEKEY, 2012). What seems urgent is the need to build a common and sharable morality based on mutual care and reciprocal respect between humans and nonhumans (natural or artificial).

\section{5 - Justifying the right to be human and the right to be posthuman}

In this last section, I provide justification for the entitlement to remain human and the claim to become posthuman. If we accept a community of multiple kinds of agents (robots, nonhuman animals, transhumans, natural humans, posthumans, digital ones etc.) - all of them persons - then there is no reason not to grant an extrinsic right to remain human for those who are willing to do so, nor is there any reason not grant the right to those planning to overcome our biological condition to become posthuman.

To imagine how such a transmutation could occur, we need only recall the movie Bicentennial Man. In it a robot wants to become human and keeps trying until he finds the singular feature that supposedly marks out humanity, and ends up dying beside his loved one. As I said above, I do not see any moral reason why in the future a robot could not become human or vice versa so long as personhood is preserved. Whether this is technically possible is a different kind of problem, but unless we believe in an immutable human essence, there is no reason to hold that transmutation from human to nonhuman or from to nonhuman to human cannot be done. The assumption here refers only to a kind of human condition, something proper to our lifeform, not a Platonic form of mankind. Again, if personhood is preserved, there is no moral objection not to transform oneself. 
How can we ground the right to remain human? Well, given the plurality of worldviews, some based on metaphysical beliefs, we should allow those willing to remain human because they have specific religious beliefs to do so. Taking seriously what John Rawls, in Political Liberalism, calls "the fact of reasonable pluralism" (1993, vii), if an individual believes humans are made imago dei and does not want "to play God" by changing her condition, she has the right to remain human. She must, however, respect those who do not have the same religious belief and do want to change their nature. Therefore, a deeply totalitarian institution, say an autocratic world state governed by a despotic dictator, could neither force a human to become posthuman nor vice versa.

At this point one may object that the system of intrinsic rights described above needs further justification. I have been arguing that one may transform oneself so long as personhood is preserved and, consequently, some basic rights are assured together with the corresponding obligations. But why should one accept such an apparently deontological account of morality based on rights to make permissible posthumanism? To this objection, I would first like to point out that we cannot continually ask for one justification after another. It reveals, to put it in Aristotelian terms, a lack of a good philosophical education, or, to use a Wittgensteinian metaphor, an unawareness of when we have reached rock bottom. Thus, I would like to present another, final, philosophical justification to adopting the above system of intrinsic rights based on a first ethical principle, which I assume is a kind of hinge proposition capable of unifying the three main normative approaches, namely consequentialism, deontology and virtue ethics. It is based on Parfit's Triple Theory, although I have substantially reformulated it. Thus, we could say that acts which violate an intrinsic right are not allowed by an optimific, uniquely universally willable principle that a virtuous person would follow. First ethical principle (or metaprinciple) is capable of justifying a common morality based on mutual care and reciprocal respect that we can all share as persons, humans or nonhumans (DALL'AGNOL, 2016, 73f, for further details).

To end, it is worth pointing out that one of the main objectives in this article was to show that the idea of human rights will not become obsolete in a posthuman 
era. Thus, no matter how much science and technology progress, if the argument set out here makes sense, we have a solid system of rights to protect both human and nonhuman rights.

\section{Final remarks}

In this paper, I wanted to highlight the idea that human rights still make sense and are, in fact, becoming even more important, despite the new challenges from many scientific and technological innovations (genetic engineering, AI etc.), which give rise to the prospect of a posthuman world and even the end of humanity.

Finally, I would like to emphasize that the spirit in our current age of great achievements cannot just be to be against everything, but to borrow Buchanan's expression, we need to be at least "anti-anti-enhancement" (2015, p. 14). Otherwise, the debate will not progress. It does not make sense to be against neuro or bioenhancement or the creation of autonomous robots if we have a sound ethics capable of granting a system of rights to any kind of agent, human and nonhuman alike, that is, for all persons.

\section{References}

AMERICAN CONVENTION ON HUMAN RIGHTS. 2011. Retrieved from: $<$ https://www.oas.org/dil/treaties_b-32_american_convention_on_human_rights.pdf $>$.

BENTHAM, J. The principles of morals and legislation. New York: Hafner Press, 1948.

BUCHANAN, A. Beyond bumanity? Oxford: Oxford University Press, 2013.

CRUFT, R.; LIAO, S. M.; RENZO, M. (Eds.). Philosophical foundations of human rights. Oxford: Oxford University Press, 2015.

CRISP, R. (Ed.). Griffin on human rights. Oxford: Oxford University Press, 2014.

DALL'AGNOL, D. Care and Respect in Bioethics. Newcastle: Cambridge Scholars, 2016.

DALL'AGNOL, D. La ética de Wittgenstein y el problema del relativismo. València: Publicaciones de la Universidad de València, 2016.

WALL, F. Bonobo. The forgotten ape. Berkeley: University of California Press, 1997. 
EDMUNDSON, W. A. An introduction to rights. Cambridge: Cambridge University Press, 2004.

EVANS, T. Human rights fifty Years on. A reappraisal. Manchester: Manchester University Press, 1998.

FUKUYAMA, F. Our poshuman future: Consequences of the biotechnology revolution. London: Profile Books, 2003.

GRIFFIN, J. On human rights. Oxford: Oxford University Press, 2013.

HABERMAS, J. Die Zukunft der menschilichen Natur. Frankfurt: Suhrkamp, 2001.

HOBBES, T. Leviathan. Cambridge: Cambridge University Press, 1992.

HOHFELD, W. N. Fundamental legal conceptions as applied in judicial reasoning and other essays. New Haven: Yale University Press, 1919.

HUXLEY, A. Brave new world. New York: Harper, 2006.

KANT, I. Practical philosophy. Cambridge: Cambridge University Press, 2008.

KURWEIL, R. The singurality is near: When bumans transcend biology. New York: Viking Penguin, 2005.

LANPHIERS, E. et al. Don’t Edit the Human Germ Line. Nature, 519, 26 March 2015. p. 41

LEWIS, C. S. The abolition of man. Oxford: Oxford University Press, 1943.

LIN, P.; ABNEY, K.; BEKEY, G. A. (Eds.). Robot ethics. The ethical and social implications of robotics. London/Mass.: The MIT Press, 2012.

LOCKE, J. Two treatises of government. Cambridge: Cambridge University Press, 1994.

PARFIT, D. On what matters. Oxford: Oxford University Press, 2013.

OVIEDO CONVENTION. 1997. Retrieved from: <http://www.gddc.pt/siii/docs/oviedo.pdf>.

PIETRZYKOWSKI, T., \& STANCIOLLI, B. (Eds.). New approaches to the personhood in law. Essays in legal philosophy. Frankfurt am Main: Peter Lang, 2016.

RAWLS, J. Political liberalism. New York: Columbia University Press, 1993.

SANDEL, M. The case against perfection. Harvard: Belknap Press, 2007.

SAVULESCU, J.; BOSTROM, N. (Eds.). Human enbancement. Oxford: Oxford University Press, 2009.

SAVULESCU, J. et al. (Eds.). Enhancing Human Capacities. Oxford: Wiley-Brackwell, 2011.

SHUE, H. Basic rights. Subsistence, affluence, and U.S. foreign policy. Princeton: Princeton University Press, 1980.

The B.R.A.I.N. Retrieved from: <www.braininitiative.org>. 
TUGENDHAT, E. Vorlesungen über Ethik. Frankfurt am Main: Suhrkamp, 1994.

PARIJS, P. Real freedom for all. What (if anything) can justify capitalism? Oxford: Oxford University Press, 2003.

UNIVERSAL DECLARATION ON BIOETHICS AND HUMAN RIGHTS. 2005. Retrieved from: <http://unesdoc.unesco.org/images/0014/001461/146180por.pdf>. Access in: 22 fev. 2018.

UNIVERSAL DECLARATION ON HUMAN RIGHTS. 1948. Retrieved from: <http://www.onu.org.br/img/2014/09/DUDH.pdf>

WITTGENSTEIN, L. Philosophical investigations. Oxford: Blackwell, 1999.

RECEIVED: 01/29/2020

APPROVED: 02/12/2020

RECEBIDO: $29 / 01 / 2020$

APROVADO: $12 / 02 / 2020$ 